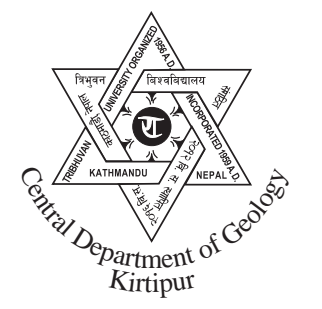

\title{
Quaternary stratigraphy of Panchkhal valley, Central Nepal
}

\author{
*Yadu Nath Timsina and Prakash Chandra Adhikary \\ Central Department of Geology, Tribhuvan University, Kathmandu, Nepal
}

\begin{abstract}
The Panchkhal Valley is one of intermontane basins in the Central Nepal east of Kathmandu with two sets of neo-tectonic lineaments sited from satellite imagery and aerial photographs. One extending NNW-SSE east of the valley results the old Panchkhal Valley uplifting along south during Plio-Pleistocene age and second one NE-SW has ultimately uplifted the old valley. The Panchkhal Clay, Ratopairo Formation, Rampur Formation and Tamaghat Formation are four depositional lithostratigraphical units. Similarly, Tamaghat, Rampur, Thumka, and Chisapani surfaces are depositional and Basukidada, Sano-Tinghare, Sumara-Thulo Tinghare, Dhulikhel, Koiralathumka and Bhamarkot surfaces are erosional morphostratigraphic geomorphic surfaces. Geomorphic terrace cutting level is around 1400-1440 m and all surfaces and deposits above and below are relatively young.
\end{abstract}

\section{INTRODUCTION}

The Panchkhal Valley, intermontane basin developed in the southeast of the Kathmandu Valley is located within the eastern flank of a synclinorium in Kavre District (Stocklin 1980). The Jhiku Khola, a tributary of the Sun Koshi River is characterised by development of geomorphic surfaces at different elevations formed after the last glacial retreat in the area. Glacial strand retreat and fluvial incision led to develop landscapes and evolve the area having a relief of about 122 to $750 \mathrm{~m}$. This paper describes neotectonic framework and morphostratigraphic units of the Panchkhal Valley. Aerial photographs and satellite imagery of the valley were used to trace out the lineaments.

\section{NEOTECTONIC FRAMEWORK}

Geomorphic surfaces show low relief and continuous features. Terrace edges are considered as indicators for the detection of neo-tectonic units. The lineaments across the present basin cross-cut the existing tectonic discontinuity such as the Mahabharat

\footnotetext{
*Corresponding author:

E-mail address: sharmayadunath@gmail.com
}

Thrust (MT). Abrupt change in terrace elevation associated with observed lineaments at Khok Village and at Okhare Village signifies that they are neotectonic in origin.

Two type of lineaments were recognised, of which the first extends along NNW-SSE passing from the east of the Panchkhal Valley along the Cha Khola and eastern ridge. It has uplifted the southern block of the valley during the Plio-Pleistocene time resulting formation of an old Panchkhal valley with a thick black clay. Regionally, the fault is sinuous and is comparable with the Mahabharat Thrust (Stocklin 1980). The Mahabharat Thrust (MT) was active during the Middle Pleistocene. The axis of the elongated valley (NNW-SSE) is almost parallel to the MT that also supports its genetic relationship with the MT. The second group of NE-SE lineaments extends almost right angle to the MT (Fig. 1). Three major successive neo-tectonic lineaments, namely Okhre Khola, Dhulikhel Khola and Punyamati-Cha Khola Lineaments from south to north of Basukidada are found to be associated with identified geomorphic surfaces.

The Okhre Khola Lineament passes from the south of the present valley floor. The Dhulikhel Khola 


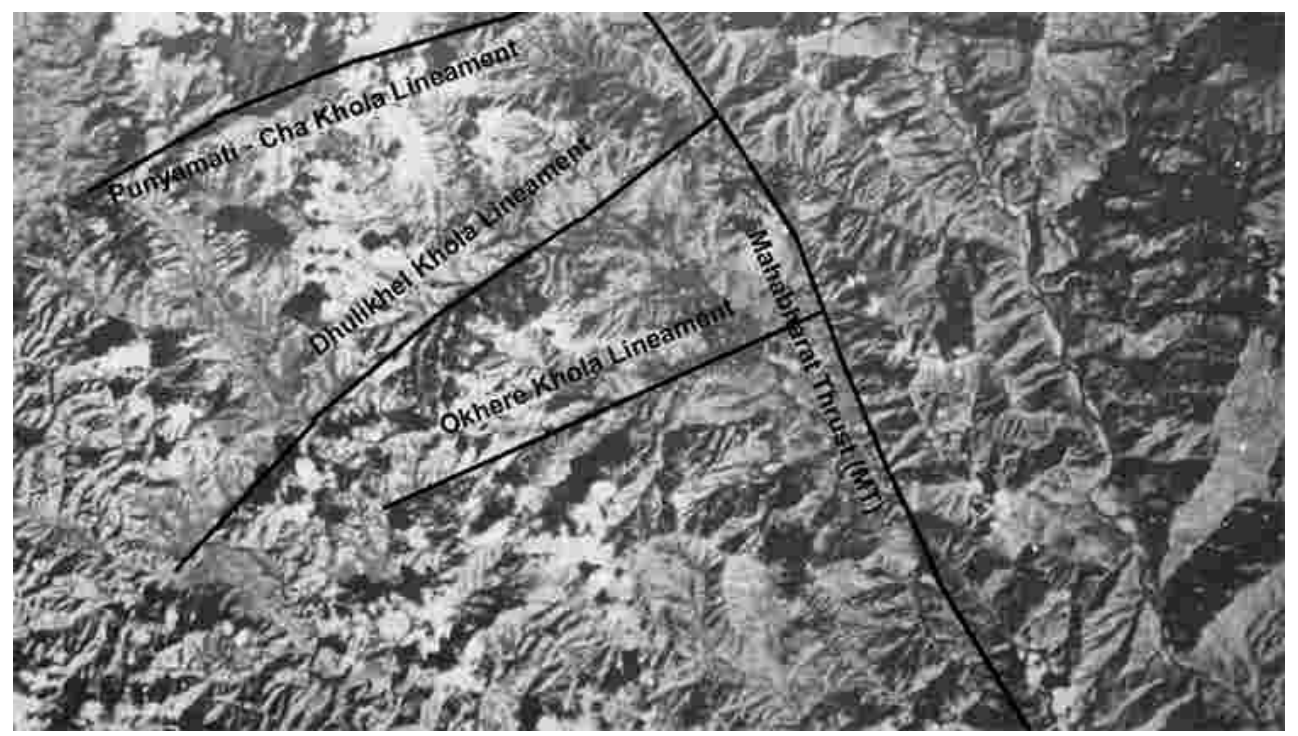

Fig. 1 Major tectonic

lineaments in the Panchkhal Valley

Lineament passes through the Dhulikhel River. These lineaments have raised the Panchkhal Clay. After the depost of thick black clay, the fluvial sediments were deposited in the central part of the valley covering the clay, and debris flow deposited at the periphery. This gave rise to a wide intermotane basin between the lineaments. The lake would have drained momentarily along the Jhiku Khola gorge at the southern part of the valley. Punyamati-Cha Khola Lineament triggered rejuvenated fluvial incision which in its course led to headward nick-point migration very near to the water divids clearing the last glacial geomorphic surface. The neotectonic activities along the faluts sculptured the existing geomorphic surfaces. The activities continue even at present.

\section{QUATERNARY STRATIGRAPHY}

The quaternary stratigraphy of the Panchkhal Valley has been established based on field work focused on the northern area of the valley, however the stratigraphic units are also distributed in other parts of the valley. The deposit in the area is represented by terraces and debris flow at different elevations including thick buried black clay which does not form present-day landform. The geomrohphic higher elevations suffer intense erosion and mass movements erasing former evidences of landform development, which are difficult to date absolutely. These surfaces were dated relatively on the assumption that landform assemblages are a palimpset of superimposed part of different erosional cycles each initiated by a change of base level of tectonic or eustatic origin (Chorley et al. 1985). Geomorphic height of a particular surface can be dated relatively by morphostratigraphical criteria as described by Adhikary and Thapa (2001).

\section{Morphostratigraphy}

Morphostratigraphy units were first identified geomorphic surfaces in the aerial photographs $(1: 50,000)$ and topographical map $(1: 25,000)$ which was verified by field ground-truthing and were relatively dated on the basis of their absolute heights, general soil rubification, and terrace cutting levels. The geomorphic surface of $1400 \mathrm{~m}$ was considered as the terrace cutting level, a marker surface for the area, as other geomorphic surfaces above and below were relatively younger and were similar in composition and elevation with the oldest geomorphic surfaces of Middle Pleistocene age (?), which are represented by the erosional Kotol Formation and Swayambhu/Kirtipur Surface in the adjacent Kathmandu Valley (Adhikary and Thapa 2001).

Morphostratigraphic units of the Panchkhal Valley and its surrounding hills were broadly classified into the depositional and erosional surfaces (Fig. 2; Tables 1 and 2).

\section{Depositional morphostratigraphy}

Morphological depositional surfaces are represented by a series of terraces between $880 \mathrm{~m}$ 


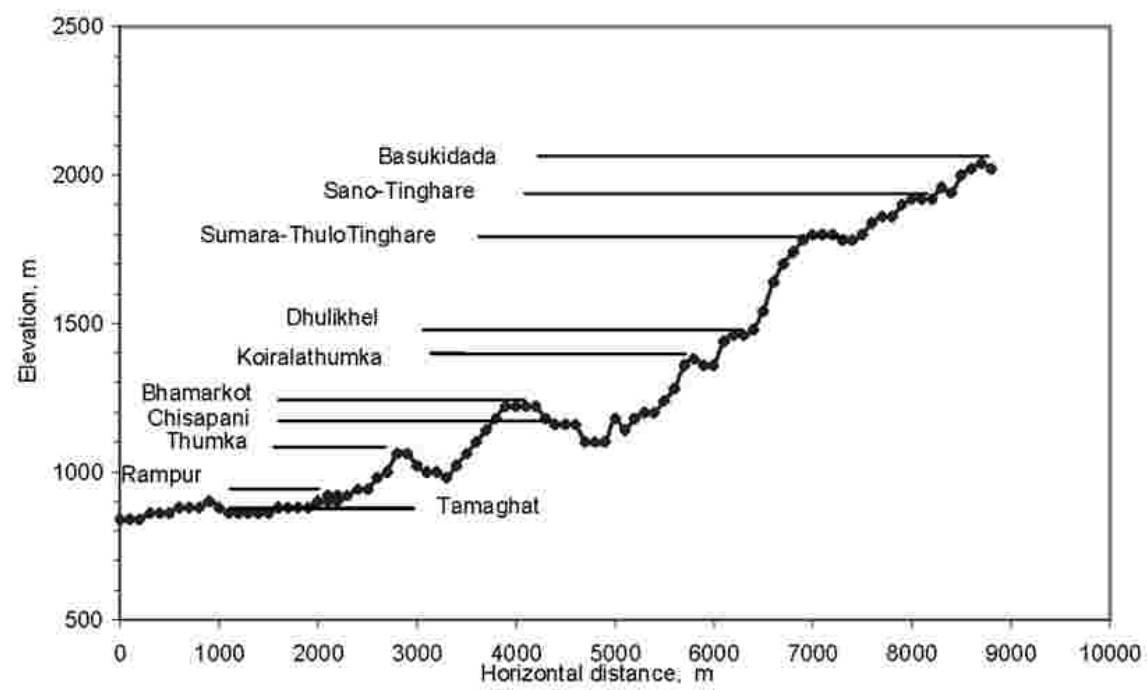

Fig. 2 Morphostratigraphic surfaces of the Panchkhal Valley

Table 1: Depositional morphostratigraphic units

\begin{tabular}{llll}
\hline Unit & Thickness $(\mathrm{m})$ & Type & Probable age \\
\hline Tamaghat Surface & $<880$ & River terrace & Holocene \\
Rampur Surface & $880-920$ & Old river terrace & Last glacial stage (?) \\
Thumka Surface & $1000-1140$ & Debris deposit & Middle Pleistocene (?) \\
Chisapani Surface & $1200-1220$ & Debris deposit & Middle Pleistocene (?) \\
\hline
\end{tabular}

Table 2: Erosional morphostratigraphic units

\begin{tabular}{lll}
\hline Unit & Thickness $(\mathrm{m})$ & Type \\
\hline Basukidada Surface & 2053 & Debris deposit \\
Sano-Tinghare Surface & 1960 & Debris deposit \\
Sumara-Thulo Tinghare Surface & 1865 & Debris deposit \\
Dhulikhel Surface & $1505-1600$ & Debris deposit \\
Kairalathumka Surface & $1400-1420$ & Debris deposit \\
Bhamarkot Surface & $1340-1360$ & Debris deposit \\
\hline
\end{tabular}

and >1160 m. Three depositional morphostratigraphical landforms of the Pleistocene age and the remaining one of the Holocene age were observed as shown in Table 1. The Tamaghat Surface (present-day floodplain and braided channels of the Jhiku Khola) below $880 \mathrm{~m}$ above mean sea level (amsl) represents the lowermost and the youngest geomorphic surface in the valley (Fig. 3). The next Rampur Surface represents the first raised old river terrace forming prominent geomorphic surface at an elevation 880-920 $\mathrm{m}$ and is distribtuted around Tamaghat, Rampur and Takadihi Villages (Fig. 3). The Thumka Surface represents the next surface at
1000-1140 m amsl. The uppermost surface is represented by the Chisapani Surface at 1200-1220 $\mathrm{m}$ amsl. The Chisapani surface is underlain by debris flow deposit.

\section{Erosional morphostratigraphy}

Erosional surfaces of Pleistocene age are widely distributed at different elevations from 1360 to 2053 $\mathrm{m}$ on hills surrounding the Panchkhal Valley. They represent patchy remnants of gently slopping to almost flat surfaces and are occupied by debris flow deposits of varying age. Six erosional geomorphic surfaces were identified in the area and are as shown in Table 2. 


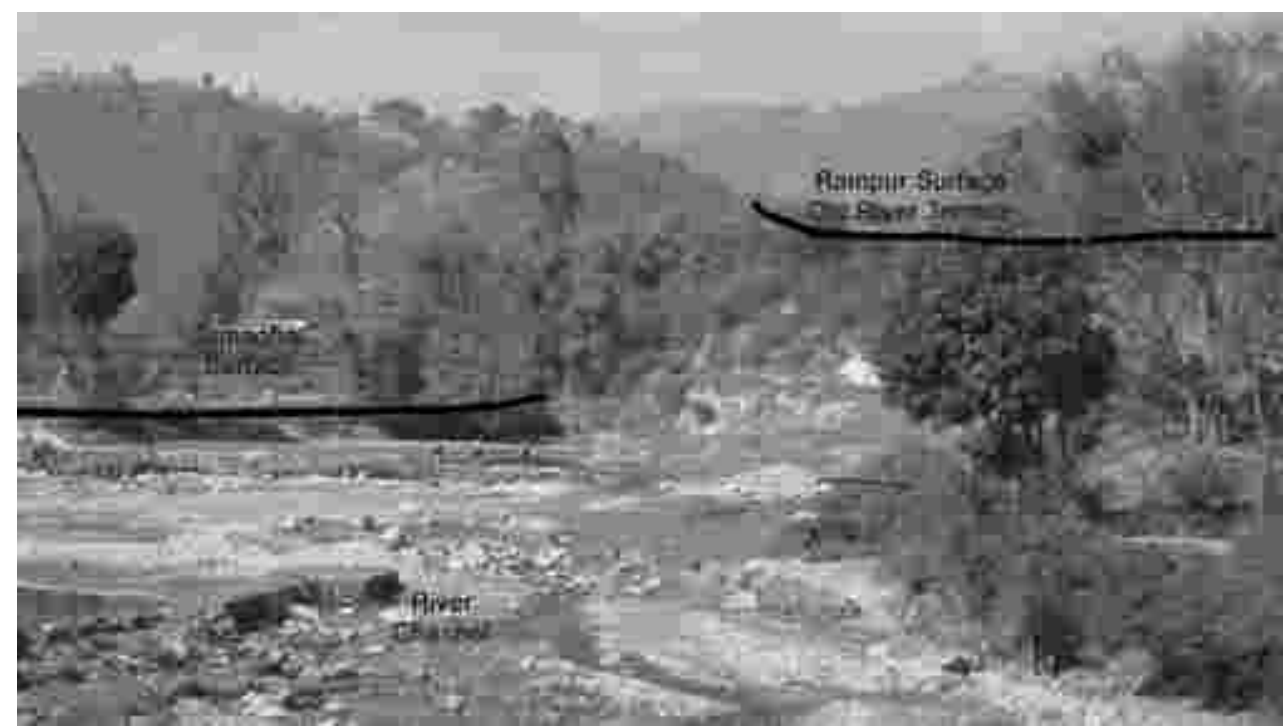

Fig. 3 Rampur Surface and Tamaghat Surface north of Tamaghat
Basukidada and Sano-Tinghare surfaces are made up of Basukidada morrains, eskers, kames and debris flows exhibiting U-shaped trough and glacial arrets above $2000 \mathrm{~m}$. U-shaped troughs on the surface at the higher elevations in the Himalaya are the good evidences of the last glacial stage (Adhikary 1993). The age of the Basukidada geomorphic surface is estimated to be of the last glacial stage. Widespread Sumara-Thulo Tinghare and Dhulikhel geomorphic surfaces respectively at $1865 \mathrm{~m}$ and $1505-1600 \mathrm{~m}$, are covered by Nala and Dhulikhel debris flow deposits. Similarly, Koiralathumka and Bhmarkot geomorphic surfaces between the Basukidada geomorphic surface and the terrace cutting level are estimated to be of the Middle Pleistocene age.

\section{Depositional lithostratigraphy}

Quarternary depositis distributed in the study area were classified into seven units of formation level (Fig. 4; Tables 3a and b).

\section{Panchkhal Clay}

West of Tamaghat, the Phanchkhal Clay is represented by weakly consolidated thick black clay with thin silt and fine sand layers in a dug well of more than eight meters. The Panchkhal Clay is buried and does not crop out on the surface. It also does not make significant relief but forms a basal stratigraphic unit that can be compared to the Lukundol Formation of age ranging from the Late Pliocene to Early Pleistocene (Tuladhar 1982; Yoshida and Igarashi 1984).

\section{Ratopairo Formation}

The ratopairo Formation is an unconsolidated debris flow deposit that overlies the Panchkhal Clay. At present it lies at the toe often covering the top of the low hills. It is primarily represented by the slopping debris flow terraces distributed at the lower elevations north of the Pachkhal Valley. The type locality of the formation is located at Ratopairo about $2 \mathrm{~km}$ north of Tamaghat. About $5 \mathrm{~m}$ thick debris and mud flow deposits cover the low-lying hilly areas around Ratopairo. The formation comprises deeply weathered red soil at top and matrix-supported angular rock fragments at bottm (Figs. 5 and 6). The formation has been severely eroded and intensely rubified. The Ratopairo Formation is older than the Rampur Formation because the former is more rubified. The age that could be attributed to the Ratopairo Formation could be Middle Pleistocene to Early Pleistocene (?) and could be correlated to Middle Pleistocene Champi Formation in the Kathmandu Valley (Adhikary and Thapa 2001).

\section{Rampur Formation}

The Rampur Formation exhibits old gentle slopping river terrace widely distributed at Rampur, Dwaredhihi, Takadihi and northeast slope of Lamdihi and east of Tamaghat. The formation comprises thick and loose sand deposit with more than $8 \mathrm{~m}$ thickness overlying the lower portion of debris deposit of the Ratopairo Formation (Fig. 7) at west of Tamaghat in newly dug well which was more than $8 \mathrm{~m}$ deep. The 

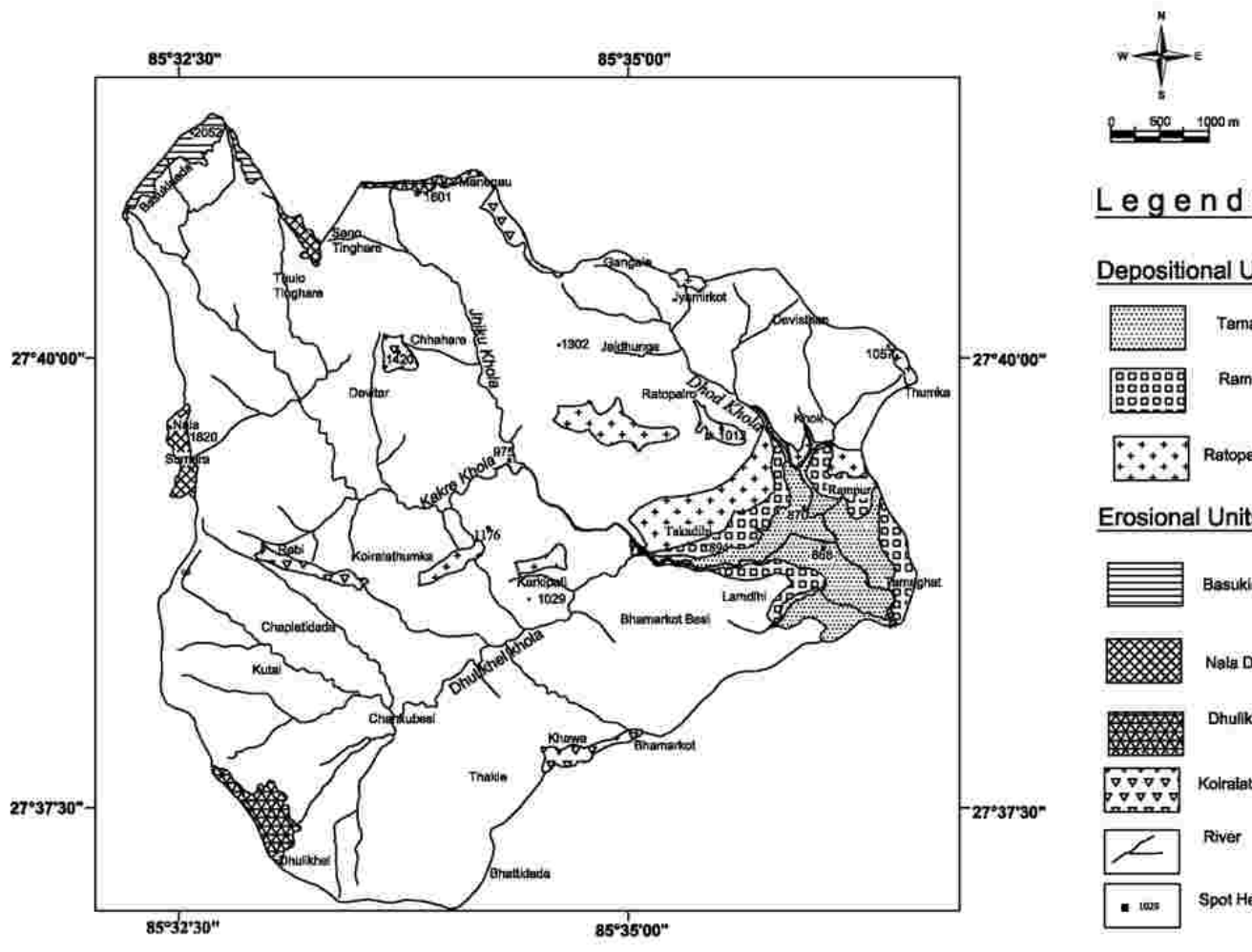

Legends

Depositional Units

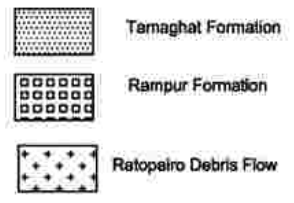

Erosional Units

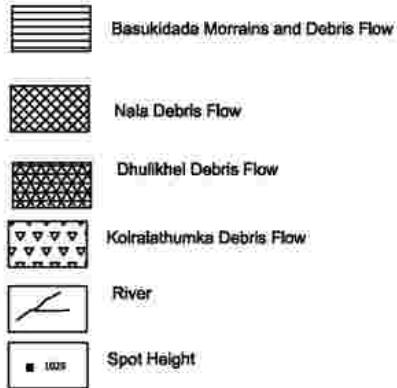

Fig. 4 Quaternary geological map of northwester region of the Panchkhal Valley
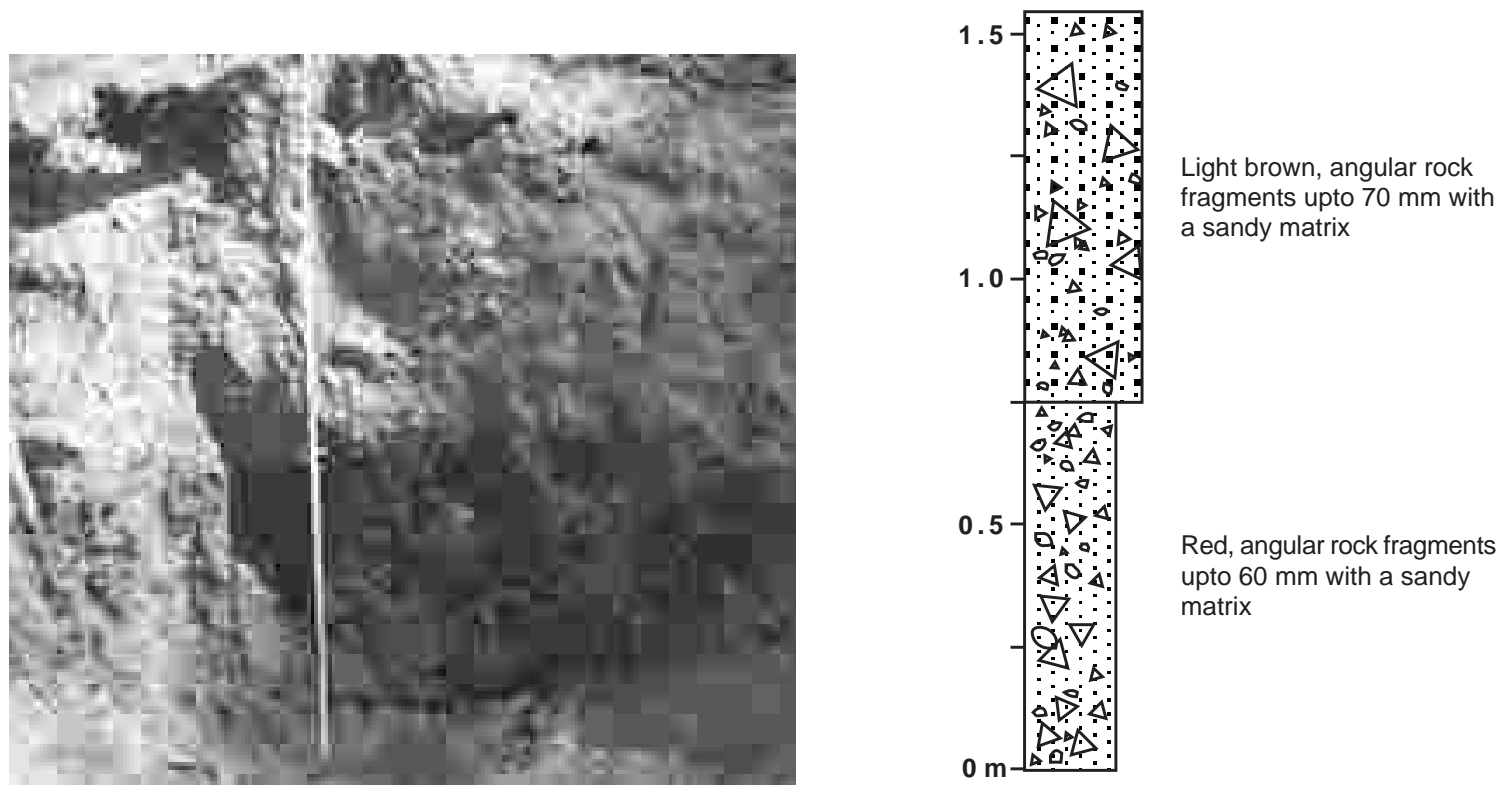

Fig. 5 Debris deposit of the Ratopairo Formation

Fig. 6 Columnar section of the Ratopairo Formation 
Y. N. Timsina and P. C. Adhikary / Bulletin of the Department of Geology, Vol. 10, 2007, pp. 1-8

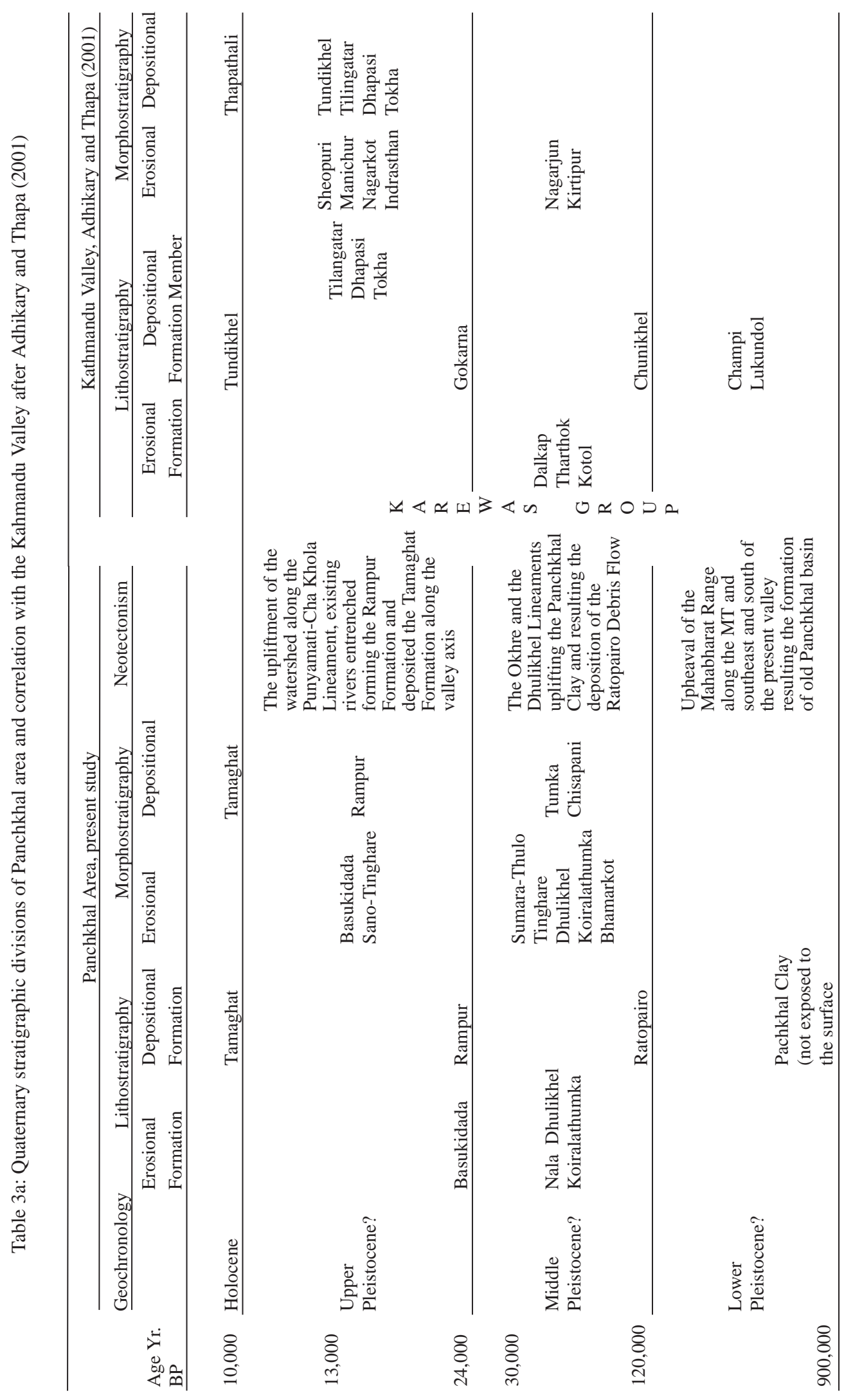


Table 3b: Stratigraphic divisions of the Quaternary sediments in the Panchkhal Valley

\begin{tabular}{|c|c|c|c|c|c|}
\hline Age Yr. BP & Geochronology & Formation & Thickness & Lithology & Neotectonism \\
\hline 10,000 & Holocene & Tamaghat & Thin? & \multirow{2}{*}{\multicolumn{2}{|c|}{$\begin{array}{l}\text { The upliftment of the watershed along the } \\
\text { entrenched forming the Rampur Formation and } \\
\text { deposited the Tamaghat Formation along the } \\
\text { valley axis }\end{array}$}} \\
\hline 13,000 & Upper Pleistocene? & Rampur & $20 \mathrm{~m}$ & & \\
\hline 30,000 & Middle Pleistocene? & Ratopairo & $5 \mathrm{~m}$ & 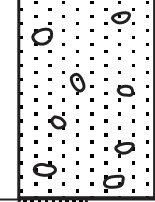 & $\begin{array}{l}\text { The Dhulikhel Lineament uplifted the Panchkhal } \\
\text { Clay and resulting the deposition of the } \\
\text { Ratopairo Debris Flow sediment }\end{array}$ \\
\hline 900,000 & Lower Pleistocene? & $\begin{array}{l}\text { Pachkhal Clay (not } \\
\text { exposed to the } \\
\text { surface }\end{array}$ & $?$ & & $\begin{array}{l}\text { Upheaval of the Mahabharat Range along the } \\
\text { MT and southeast and south of the present } \\
\text { valley resulting the formation of old Panchkhal } \\
\text { basin }\end{array}$ \\
\hline
\end{tabular}

formation is represented by old river terace and fan deposits at the foothills. The soil profile is poorly developed. The formation lies upto about $20 \mathrm{~m}$ above the present riverbed with higher terraces than of the Holocene terraces in the area. This leads the most suitable age for the Rampur Formation is the Late Pleistocene (?) comparable to the Gokarna Formation of the Kathmandu Valley (Adhikary and Thapa 2001).

\section{Tamaghat Formation}

The Tamaghat Formation is represented by Holocene deposits, present floodplain, channels and minor natural levee just above the present Jhiku Khola. The series of Holocene fluvial terraces of height less than meters are characterised by alternate layers of loose gravel and coarse to fine sand from the bottom to the top. The gravel is matrix-supported with lithology of quartzite, gneiss, granite and few schists fragments. Holocene deposit is not differentiated during this study and included in a single unit.

\section{Erosional lithostratigraphy}

Debris flow deposits are widely distributed at the gentle hill slopes and capping low-lying surrounding hills around the Panchkhal Valley. They are found as patches of hanging elongated bodies over steep hillslopes and isolated hummocky hills. The debris flow deposits contain matrix-supported poorly sorted rock fragments distributed as wide extensive hanging terraces.

\section{Koiralathumka Debris Flow}

Koiralathumka Debris Flow, the oldest debris flow in the Panchkhal Valley, is located at elevation 1420 to $1460 \mathrm{~m}$ amsl at the toe of surrounding hills as a blanket of elongated bodies. The deposits are highly weathered with intense rubification with reddish colour. The deposits comprise poory soted boulders. The Koiralathumka Debris Flow forms the oldest deposit in the valley as evidenced by its distribution around the distinct terrace cutting around the elevation $1400 \mathrm{~m}$. The type locality is proposed at Koiralathumka along the Rabi-Opi road. The deposit is also exposed around Bhamarkot and Khewa Villages. The Koiralathumka Debris Flow is interpreted as an evidence of extensive glaciations in the Himalayas representing the Gurkha Glacial Stage (Adhikari 1993). It is correlated with the Kotol Debris Flow of the Kathmandu Valley (Adhikary and Thapa 2001).

\section{Dhulikhel Debris Flow}

The Dhulikhel Debris Flow maintains an elevation between 1550 and $1700 \mathrm{~m}$ amsl particularly at foothills surrounding the Panchkhal Valley and comprises poorly sorted sediments with less intense rubification. The sediment includes sandy matrix-supported boulders. The type locality of the formation is 


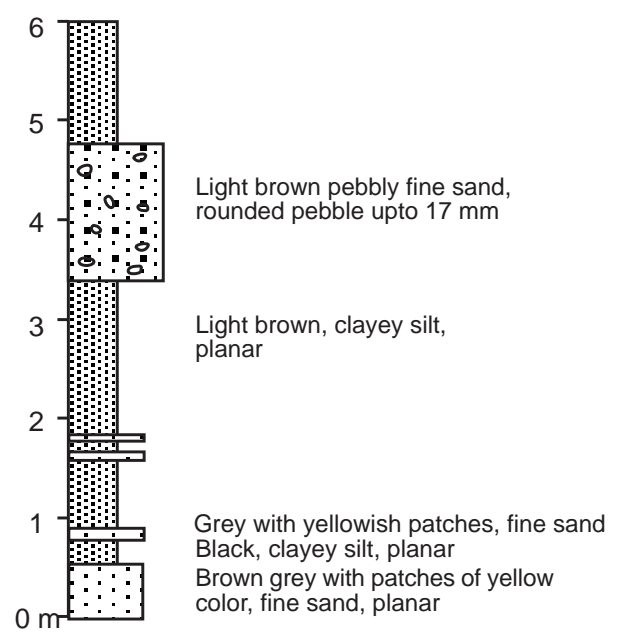

Fig. 7 Columnar section of the Rampur Formation

proposed at Dhulikhel and is widespread in Thakla, Thadagau, Kalthumki Bhanjyang and Manegau.

\section{Nala Debris Flow}

Nala Debris Flow is widely distributed at an elevation from 1820 to $1990 \mathrm{~m}$ amsl. It is distributed in the upper part of the Jhiku Khola watershed at the toe of Basukidada. The debris flow has similar lithology as the earlier two deposits, but shows no soil profile and rubification. The type locality is proposed at Nala where the the dissected flat erosional terrace at 1840 amsl represents the deposit.

\section{Basukidada Morrains and Debris Flow}

The Basukidada Morrains and Debris Flow occupies the highest elevation in the valley above 1994 to $2053 \mathrm{~m}$ amsl. It covers the hill tops of the valley. The unit contains sandy and gravely eskers and kame glacial deposits with almost no soil profile. The landscape reflected by U-shaped smooth glacial valleys at the ridges surrounding the Panchkhal Valley holds evidence of the last glacial stage. These strong glacial evidences represent the last glaciation, the Sherpa Glacial Stage in the Himalaya (Adhikary 1993). It is comparable to the Sheopuri Debris Flow of the Kathmandu Valley (Adhikary and Thapa 2001).

\section{CONCLUSIONS}

The Panchkhal Valley is one of the intermontane basins in the Central Nepal forming its landscape by the Quaternary sediments. The area bears two sets of tectonic lineaments, one extends NNW-SSE east of the Panchkhal Valley, while the second group of NE-SW lineaments has uplifted southern part of the valley forming old valley at the beginning of PlioPleistocene. The basin drained after activation of the second group of lineaments and started to deposit river sediment and raised river terraces above the present floodplain accompanied by retreating hillslopes, and therefore erasing the Pleistocene signatures. Geomorphic terrace cutting level in the area is around 1400-1440 m amsl and all surfaces and deposits above and below are relatively younging (?). The Panchkhal Clay, Ratopairo Formation, Rampur Formation, and Tamaghat Formations are depositional lithostratigraphic units. Tamaghat, Rampur, Thumka and Chisapani surfaces are depositional morphostratigraphic units while Basukidada, Sano Tinghare, Sumara-Thulo Tinghare, Dhulikhel, Koiralathumka and Bhamarkot surfaces are erosional morphostratigraphic units.

\section{ACKNOWLEDGEMENTS}

Authors are thankful to Central Department of Geology for providing facilities. Authors thank B. D. Shrestha, Department of Electricity Development, Kathmandu for providing suggestions.

\section{REFERENCES}

Adhikary, P.C., 1993. The monsoon circulation in Nepalese Himalaya: evolution and environmental thrust, Bull. Dept. Geol., Tribhuvan Univ., Kirtipur, Kathmandu, Nepal, v. 3, Special Issue, pp. 1-10.

Adhikary, P.C. and Thapa, H.B., 2001. Pleistocene geology of the Kathmandu Valley. Trivubhan University, Kirtipur, Kathmandu, Nepal, v. 8, pp. 61-72. Chorley, R.J., Schumm, S.A. and Sugden, D.E., 1985. Geomorphology. Third Avenue, Methuen \& Co., New York, pp. 22-28.

Stocklin, J. and Bhattarai, K.D., 1977. Geology of Kathmandu area and central Mahabharat Range, Nepal Himalayas. Technical Report (Unpublished), UNDP Mineral exploration project, Kathmandu, 86p.

Tuladhar, R.M., 1982. A note to the lignite occurrence in Lukundol, Kthmandu, Jour. Nepal Geol. Soc., v. 2, no. 1, pp. 47-51.

Yoshida, M. and Gautam, P,. 1988. Neogene to Quaternary lacustrine sediments in the Kathmandu Valley, Nepal. Journal of Nepal Geological Society, v. 4, pp. 73-100. 